\title{
Die aard van persoonstoename in Calvinia en omgewing: 'n pragmatiese beskouing
}

\author{
Frank Hendricks \\ Departement Afrikaans en Nederlands \\ Universiteit van Wes-Kaapland \\ BELLVILLE
}

\begin{abstract}
The nature of personal sobriquets in Calvinia and vicinity: a pragmatic perspective

This contribution focuses on the usage of personal sobriquets in the Northern Cape district Calvinia. Within the framework of a pragmatic analysis the article reflects, on the one hand, on the interaction between sobriquets and other name types and, on the other hand, on the way in which the identifying function, semantic nature and grammatical behaviour of sobriquets are intertwined. Existing studies on sobriquets from diverse theoretical perspectives are incorporated supportively and/or comparatively.
\end{abstract}

\section{Oriëntasie}

Toename/byname is 'n eeu-oue verskynsel wat reeds etlike jare lank in SuidAfrika en internasionaal vanuit verskillende gesigspunte aan wetenskaplike ondersoek onderwerp is. Toename onder Afrikaanssprekendes het tot op hede aandag gekry in onder meer studies van 'n histories-kulturele aard (vgl. Hoge, 1926 en 1945; Van Rooyen, 1961; Coetzee, 1975; Van Waart, 1975 en Van Niekerk, 1976) en in taalkundige werke op die terreine van onder meer die naamkunde (Combrink, 1977), die pragmatiek (Combrink, 1982), die dialektologie (Links, 1989) en die sosiolinguistiek (Bosch \& De Klerk, 1994). In haar bestekopname oor Suid-Afrikaanse bynaamnavorsing konstateer Bosch (1994:34 en 35) dat die oes van bynaamnavorsing binne die kader van die kerngebiede van die taalkunde (fonetiek en fonologie, morfologie, sintaksis, leksikologie, semantiek en pragmatiek) en die sosiolinguistiek tot op hede maar aan die skraal kant is en dat daar ' $n$ behoefte bestaan om byname vorentoe onder andere vanuit 'n funksionele, sosiologiese, psigologiese of sosio-historiese perspektief te bestudeer. Voorts meld sy (Bosch, 1994:35) dat daar met die oog op 'n gekoördineerde ondersoek na byname in Suid-Afrika in die eerste instansie klaarheid gekry moet word oor die inhoud van die begrip bynaam. Met inagneming van hierdie appèl word daar in hierdie bydrae gefokus op 
toenaamgewing en -gebruike in die oorwegend Afrikaanssprekende gemeenskap van Calvinia en omgewing. Binne die raamwerk van 'n pragmatiese analise van taalverskynsels word ook besin oor die mate waarin hierdie konteksspesifieke verkenning lig werp op die aard van toename. Die aanvaarbaarheid van bestaande klassifikasiesisteme en sekere vakkundige opvattings oor die wesenlike van persoonstoename word in die proses bevraagteken.

\subsection{Implikasies van 'n pragmatiese analise van toename en fokus- punte}

Die pragmatiese aanpak in hierdie artikel behels die pragmatiek as benaderingswyse tot en/of funksionele perspektief op persoonstoename as aspek van taal en nié die pragmatiek as linguistiese komponent nie (Verschueren, 1987:36; Van Dyk, 1992:23). Hierdie pragmatiese perspektief op persoonstoename is veranker in verskeie teoretiese en/of metodologiese uitgangpunte:

- Die studie en beskrywing van taalaspekte behoort sy vertrekpunt te neem binne die raamwerk van die taalgebruiksisteem (Dik, 1978:5). Holland (1990:256) se standpunt dat toename alleen sinvol geïnterpreteer kan word teen die agtergrond van die sosio-kulturele konteks waarin hulle ingebed is, is in hierdie verband ter sake:

Nicknames are used in different ways by different groups of people, and it is not possible to understand the depth of their interface with their respective societies without studying the demographic and social structures, the cultural milieu, out of which their uses arises (Holland, 1990:256).

- Taal in al sy skakerings, hetsy formeel of informeel, hetsy geskrewe taal of omgangstaal, hetsy gestandaardiseerde of substandaardvariëte, ensovoorts, kom binne die ondersoekveld van die pragmatikus. 'n Wesenlik omgangstaalverskynsel soos toenaamgebruik het derhalwe ook aanspraak op indringende taalkundige ontleding.

- Pragmatiek fokus op die verband tussen taalverskynsels en konteks (Verschueren, 1987:36) en behoort daarom metodologies toegespits te wees op twee samehangende aspekte: enersyds, 'n sentraalstelling van die gebruik van taal (-vorme) en die verklaring van vorm- en betekenissistematiek volgens funksie en, andersyds, 'n verbandlegging tussen vorm-/betekenissistematiek en kontekstuele/situasionele faktore (vgl. Hendricks, 1988:18-30; Halliday, 1973:7; Lyons, 1977:572; Fillmore, 1981:147; Levinson, 1983:22-23; Verschueren 1987:36). 
- Taalbeskrywing behoort te fokus op die pragmaties-semantiese beginsels en sosio-kulturele kragte onderliggend aan taalgebruikskeuses: "Pragmatics could be conceived as the study of the mechanisms and motivations behind any of the choices made when using language or the effects they have or are intended to have" (Verschueren, 1987:36).

- 'n Pragmatiese fokus kan sosio-histories wees (gerig op die manifestasie van taalverskynsels in taalgebruiksistuasies in die verlede), sosio-kontemporêr (gerig op taalverskynsels in 'n eietydse taalgebruiksituasie) of diachronies (gerig op veranderinge ten opsigte van taalverskynsels oor 'n gegewe periode).

Teen die agtergrond van hierdie uitgangspunte val die klem in hierdie bydrae eerstens op die identifiseringsfunksie van persoonstoename en hul status as verbandverweefde kommunikatiewe opsies. In hierdie opsig staan die besinning in opposisie met dié in byvoorbeeld die werke van Hoge (1926 en 1945) en Van Berkel (1994) waarin die fokus val op die ontstaansgeskiedenis van toename en/of die ontwikkeling van familiename/vanne uit toename. Dit gaan ook nie, soos byvoorbeeld in die ondersoek van Bosch en De Klerk (1994), om die redes vir toenaamskepping en ander toenaamfunksies soos die solidariteitsfunksie en die gebruik van toename vir die handhawing en afkondiging van sosiale norme nie. Tweedens doen die perspektief meer bepaald sosio-histories aan. Die fokus val naamlik veral op toename wat in die Calvinia-distrik reeds tussen die veertiger- en sestigerjare wyd in omloop was. As sodanig het die onderhawige taalkundige besinning meer spesifiek betrekking op toename wat in die ouer Calvinia in gebruik was, maar steeds hul natrilling in die hedendaagse Calvinia het. Die toename is almal in Calvinia en omgewing geskep, en is ten nouste vervleg met die plaaslike sosio-kulturele milieu. Hulle is wyd bekend onder Calvinianers en het derlalwe die status van ingeburgerde, openbare toename, dit wil sê persoonstoename "which are known and used by more than just those who come in personal contact with the individual" (Skipper, 1989:104). Vierdens is die fokus nie etnies-spesifiek soos in die geval van heelparty ouer studies oor toename onder Afrikaanssprekendes nie (vgl. Van Rooyen, 1961; Van Waart, 1975; Van Niekerk, 1976). Omdat toenaamtendense onder die wit en bruin bewoners van Calvinia oorwegend dieselfde is en hoogstens verskil ten opsigte van die impak van die verspreiding van ekonomiese mag, kom die toename vir wit en bruin bewoners gesamentlik onder die soeklig. Die meerderheid toename is egter dié van bruin bewoners.

Omdat persone gevoelig mag wees oor die gebruik van hul toename in 'n wetenskaplike uiteensetting, word die juiste identiteit van toenaamdraers so ver moontlik verbloem deur of hul amptelike name nie te vermeld nie, of hul name of vanne as " $X$ " aan te dui. In gevalle waar die identiteit van die draers ter 
toeligting van bepaalde toenaamaspekte wel geëkspliseer word, word dit gedoen in die veronderstelling dat dit nie aanstoot sal gee nie.

\subsection{Die databasis}

Die besinning in hierdie artikel is gebaseer op die bevindinge van 'n naamkundeprojek wat ek in die periode 1994 tot 1996 in Calvinia en omgewing geloods het. Die projek, getiteld 'n Ondersoek na die Afrikaans van Calvinia en omgewing - fokusterrein l: Naamgewing in Calvinia en omgewing, is gefinansier uit die UWK-Navorsingsfonds. Met die oog op 'n sosio-historiese beeld is die toenaamdata versamel deur middel van bandopnames van onderhoude met gevestigde inwoners van die dorp wat meestal ouer is as sestig jaar en derhalwe goed vertroud is met die geskiedenis van Calvinia en sy inwoners. Inligting is ingewin oor die amptelike name en toenaambenoemings van vroeëre en huidige gevestigde inwoners van Calvinia, asook die moontlike oorsprong van toename. Opvallend was die groot mate van ooreenkoms insake die inligting wat die onderskeie respondente verskaf het. Hierdie verkreë inligting is grootliks 'n bevestiging van insig wat ekself bekom het op grond daarvan dat ek my vormingsjare tussen 1952 en 1963 in Calvinia deurgebring het en sedert ons gesin se verhuising na Kaapstad in 1964 gereeld besoeke aan die dorp en omgewing gebring het. Naas hierdie empiriese inligting is toenaamdata ook opgeteken uit enkele bronne wat handel oor die vroeë geskiedenis van Calvinia (vgl. o.a. Anon., 1955; Smit, 1946; VLV Calvinia, 1968). 'n Totaal van 372 toenaambenoemings is in die proses geïsoleer en geïnterpreteer ten opsigte van funksie, betekenisskakeringe en grammatiese gedrag. Die statistiese bevindinge (kyk bylaag) word in die bespreking betrek.

\subsection{Tersaaklike inligting oor Calvinia en distrik}

Calvinia is 'n dorp geleë in die Hantam, 'n substreek van die Groot Karoo. Ooreenkomstig die vroeëre geografiese indeling vorm die dorp 'n deel van die noordwestelike Kaapprovinsie. Tans ressorteer dit onder die kiesafdeling NoordKaap. Die dorp is in 1847 gestig en het aanvanklik Hantam geheet (Smit, 1946). Die distrik beslaan 'n hele netwerk van plase. Die primêre ekonomiese aktiwiteite was vanaf die begin veeboerdery (veral met skape) en die verbouing van landbouprodukte (hoofsaaklik koring). Die huidige inwoners is nasate van veral trekboere van Nederlandse, Duitse en Franse afkoms wat die distrik in die agtiende eeu betrek het, Jode en Engelse wat hul intrek onderskeidelik in die vyftiger- en tagtigerjare van die neëntiende eeu geneem het en die Khoi-San wat die gebied reeds bewoon het met die aankoms van die trekboerpioniers (CreweBrown, 1992). Hoewel Nederlands, Engels, Afrikaans en die Khoi-Santale vroeër as voertale gebruik is, is die inwoners tans op enkele uitsonderings na almal Afrikaanssprekend. Die dorp en distrik is vir die grootste deel van sy 
geskiedenis gekenmerk deur 'n dominansie van die Calvinistiese kultuur met die Nederduitse Gereformeerde Kerk en die skool as sosiale organe (Smit, 1946), asook aparte woongebiede, kerke en skole vir wit en bruin bewoners, en ekonomiese beheer deur wittes.

\section{Bespreking}

Persoonstoename is informele herdopings - "meaningful, usually descriptive names, which are bestowed on individuals in addition to their given names, often at a later date" (Alford, 1987:82). In die vakliteratuur bestaan daar nie alleen meningsverskil ten opsigte van onder meer die bereik van die begrip "toenaam" en verskille insake die semantiese kategorisering van toename nie, maar ook bepaalde aanvegbare standpunte - aanvegbaar omdat reële taalgebruik nie genoegsaam verreken word nie. Landman (1986:168-169) se toekenning van toenaamstatus aan voornaamderivate en troetelvorme en Combrink (1977:40) se onderverdeling van persoonstoename in identifiserende en skertsende/spottende toename, byvoorbeeld, is in hierdie verband ter sake. Die aanvaarbaarheid van hierdie en ander standpunte word vervolgens beredeneer teen die agtergrond van die manifestasie van toename in die Calvinia-distrik (verderaan net Calvinia).

\subsection{Die bereik van die begrip toenaam}

\subsubsection{Die verhouding tussen toename en amptelike name}

Persoonstoename/-byname word in die vakliteratuur beskryf as toevoegings tot amptelike name (Alford, 1987:82; Combrink, 1977:40; Van Berkel, 1994:52), of as plaasvervangers vir amptelike name (Landman, 1986:167; Bosch \& Victor, 1996:105). Hierdie karakterisering van persoonstoename blyk in hoofsaak betrekking te hê op die ontologiese status van persoonstoename oftewel hul bestaan as name "naas" amptelike name van individue (Bosch, 1994:28; Bosch \& De Klerk, 1994:42; Bosch \& Victor, 1996:105). Vir' 'n beter verstaan van die aard van toename sou hierdie begrippe ook aangewend kon word ter karakterisering van (a) die grammatiese gedrag en/of plasing van toename ten opsigte van die amptelike voomame en/of vanne van persone en (b) die gebruikstatus van 'n persoon se toenaam in relasie tot sy ander name.

Wat grammatiese gedrag en/of plasing betref, is 'n egte toenaam (d.i. 'n betekenisgelaaide/konnoterende herdoping) 'n leksikale bousel wat soos volg optree:

Voornaamvervangend: X Gouws $>$ Duifie Gouws

Vanvervangend: Hendrik Van Wyk $>$ Hendrik Tier

Voornaam-en-van-vervangend: Gert X $>$ Kaffer-Duusman 
Aanvullend (vooropgeplaas): Lang Jan Koenana

Aanvullend (agteropgeplaas): Sarel Christians senior

Wat gebruikstatus betref, is 'n egte toenaam selde 'n substituut vir 'n persoon se amptelike benaming in die geheel. Dit is in hoofsaak slegs naam- en naam-envan-vervangers wat selfstandig gebruik kan word om 'n gegewe referent te identifiseer:

Naamvervangend: Sinnie (< Frank Hendricks) is oorlede

Naam-en-van-vervangend: Waspop (< Annie Jack) was 'n koekbakster

'n Toenaam tree egter meestal op in kombinasie met 'n persoon se voomaam (Jan Byl, Mal Dawid), van (Tôtie Mathys) of naam plus van (Klein-Jan van Schalkwyk). Om hierdie gebruiksverskeidenheid te ondervang, kan die begrip toenaambenoeming/toenaamkonstruksie benut word. Hieronder word dan verstaan of 'n toenaam wat gebruik word om 'n persoon se amptelike naam en/of van in die geheel te vervang (Spykerbalsem < Appollis Slinger) of 'n taalgebruikseenheid met 'n toenaam as onderdeel (Hendrik Tier, Mal Dawid).

Volgens die databasis is naam-en-van-substituerende toenaamkonstruksies tipies eenledig maar ook tweeledig. Die eenlediges staan in gebruiksopposisie met voornaamvervangende toename. Terwyl voomaamvervangers vryelik saam met of sonder die van gebruik word, word eenledige naam-en-van-substituerendes byna nooit in kombinasie met die van gebruik nie:

\section{Naamvervangers:}

Koen van $Z y l /$ Koen woon in Newtown

Bok Mathys/Bok was 'n boukontrakteur

\section{Naam-en-van-vervangers:}

Katbienie ( $<$ Jakobus X) het Kaap toe verhuis

Kosyn (< Lodewyk X) was baie geduldig

By tweeledige naam-en-van-substituerende toenaamuitdrukkings vervul die eerste en tweede lid onderskeidelik die funksie van "nuwe" naam en van:

\section{Johanna $\mathrm{X}>$ Nôintjie Kat, Joseph $\mathrm{X}>$ Tiekie Rooikop}

As gebruiksubstituut kan 'n toenaambenoeming (hetsy as substituerende of as toenaambevattende entiteit) sosiaal so ingeburger of verbreid raak dat dit ter identifisering van 'n persoon sy amptelike benaming verdring. 'n Implikasie hiervan is dat ' $n$ toenaambenoeming, soos in Calvinia, dikwels aangewend kan word sonder dat die gebruiker die draer se amptelike naam ken. 


\subsubsection{Die verhouding tussen toename en derivate van amptelike name}

Soos aangetoon, ken Landman (1986:168-169) toenaamstutus toe aan voornaamafleidings - 'n standpunt wat hy deel met onder meer Holland (1990;266), Leslie en Skipper (1990:253) en Bosch en Victor (1996:108-110). Persoonsnaamgebruike in Calvinia noop 'n mens egter om vervormings van amptelike benaminge en toename op grond van verskeie oorwegings as verskillende persoonsnaamtipes te beskou. Voornaamderivate (Kolie < Jakobus, Hentop < Hendrik) en vanderivate (Hennie < Hendricks, Stony < Steenkamp) staan nie alleen vormlik nie maar ook pragmaties-semanties nader aan amptelike benaminge as aan toename. Die amptelike benaminge van persone (hetsy as voornaam alleen of as van alleen of as voornaam plus van) is in die woorde van Bosch en De Klerk (1994:48) gebruiksmatig meer bepaald "arbitrêre etikette wat (...) denoteer sonder om te konnoteer". Hierdie karakterisering geld ook vir voornaamvervormings.

Anders as egte toename is laasgenoemde nie latere toevoegings tot die doopname van persone nie. Voornaamvervormings kry reeds rondom die geboorte van persone beslag, en meer dikwels vóór die doopseremonie of amptelike registrasie. Die vervorming geskied ook volgens konvensionele patrone: Jakobus word Koos, Kosie, Kohus, Kowis of Kolie, Katrina word Kaatjie, Trinie of Tryntjie, ensovoorts. 'n Konsekwensie hiervan is dat hierdie derivate in 'n gebied soos Calvinia volgens gebruikstatus eintlik informele hoofiname is. In teenstelling met egte toename wat grootliks verdringende substitute vir amptelike benoemings is, is hierdie derivate volgens die gebruik daarvan meer bepaald eerder funksionele ekwivalente/variante van amptelike name. Dat toename 'n andersoortige naamstatus as derivate van amptelike benaminge het, en laasgenoemde as identifiseringsinjale aan amptelike name gelykwaardig is, blyk ook daanuit dat hulle in heelparty toenaamuitdrukkings (soos voomame) in kombinasie met voornaamvervormings gebruik word: Daantjie (< Daniël) Veishande, Koos (< Jakobus) Kloek, Kolie (< Jakobus) Soetpap, Sofie (< Sofia) Kas, Stony (< Steenkamp) .Job.

\subsubsection{Die verhouding tussen toename, respektitels en troetelvorme}

As omgangstaalbenoeming vir 'n persoon staan 'n toenaam in die gemeenskap van Calvinia in konkurrensie met ander omgangsbenaminge soos respektitels (oom, ant(ie), ouma, oupa) en troetelvorme (soos Wêkie, Takevleis en Hondemanhoer vir my moeder, Lenie, en twee broers Isak en Johann). Toename verskil van respektitels en troetelvome ten opsigte van die gebruik as bespreek-/ verwysvorme (noemname) en as aanspreekvorme/vokatiewe (roepname). Terwyl respektitels en troetelvorme vry algemeen sonder kwetsende gevolge verwysend en vokatiwies ingespan word, word toename (veral dié van 'n pejoratiewe aard) meer bepaald net verwysend aangewend aangesien die vokatiwiese gebruik 
daarvan die draer mag ontstig. Combrink (1982:12) konstateer in hierdie verband:

Toename word gewoonlik net verwysend gebruik en dan agter die draer se rug. Die beledigende, verwysende gebruik van byname waar die draer ' $n$ toevallige of deelnemende hoorder is, het dikwels kwaai persoonlike gevolge (...). Die vokatiwiese gebruik van sulke name is gewoonlik kwetsend en neerhalend.

Tweedens verskil toename van troetelvorme en respektitels in Calvinia ten opsigte van graad van verbreidheid. Laasgenoemde twee naamtipes is wat gebruiksfeer betref, beperk tot kleiner, intieme sosiale groeperinge soos die gesinsopset, die familiekring en vriendekring. Toename, daarenteen, is sosiaal verbreid, dit wil sê hulle word as addisionele benamings vir persone in die breë samelewing gebruik. Die ondersoek toon dat respektitels en troetelvorme egter toenaamstatus kan aanneem deurdat die respeks- en vertroetelingsbetekenis daarvan (deur herhaaldelike gebruik en die opheffing van die sosiale afstand tussen gesin, familie en breë gemeenskap) geheel en al verbleek, en in die proses heel dikwels die draer se amptelike voomaam geheel en al verdring. Heelwat bruin bewoners is draers van sodanige respektitels en troetelvorme wat tot toename verbleek het:

\section{Verbleekte respektitels:}

Boetie Diergaardt, Boetie Lombard; Ousie Kok, Ousie Pop;

Suster Bailey, Suster Farao; Uncle Speelman, Uncle Jonnie Politiek

\section{Verbleekte troetelvorme:}

Baby Pieters, Baby van Zyl; Koekie Speelman, Koekie Sass; Mannetjies Speelman, Mannetjies Klaasen; Meidjie Diergaardt, Meidjie Mouton

Dit is onder meer ten opsigte van hierdie meer eksemplariese aard dat verbleekte respektitels en troetelvorme van egte toename verskil. 'n Egte toenaam is naamlik in die reël van toepassing op 'n enkele individu. Die verbleektheid van hierdie benaminge blyk onder meer daaruit dat hulle by verwysing of vokatiwiese gebruik deur 'n respektitel voorafgegaan word kan word: ant Suster Bailey, neef Mannetjies, oom Boetie Diergaardt. Verbleekte respektitels en troetelvorme verskil ook van egte toename daarin dat hulle uitsluitlik naamvervangend optree. Saam met Landman (1986) bestempel onder meer Holland (1990:266), Lawson et al. (1990:253), Bosch en De Klerk (1994:46) en De Klerk en Bosch (1996:182183) troetelvorme as toename/byname. In die lig van die bevindinge van die onderhawige ondersoek kan hierdie standpunt alleen beaam word mits troetelvome as verbleekte entiteite veronderstel word. 


\subsubsection{Die verhouding tussen toename en voorlettername}

Voorlettername soos Ef vir Frederik Gouws en naam-en-van-akronieme soos $A$ Louw vir Arthur Louw (met die fonologiese aksent op die van) het 'n tweeslagtige aard. Vormlik is hulle verwant aan voornaam- en vanderivate, maar ten opsigte van betekenis en gebruikstatus toon hulle 'n ooreenkoms met verbleekte respektitels en troetelvorme. Betekenisgewys is hulle ook nie-konnoterende identifiseringsinjale. Volgens gebruikstatus is hulle ook sosiaal verbreide entiteite wat die amptelike name van die draers verdring het. Voorlettername tree soos verbleekte respektitels of in kombinasie met vanne op of as naam-en-vanvervangers: Ef/Ef Gouws was 'n kranige rugbyspeler. Naam-en-van-akronieme word konsekwent slegs naam-en-van-vervangend gebruik: A-Louw was 'n bekende klavierspeler. Op grond van hierdie ooreenstemmende kenmerke sou hulle saam met onder meer Landman (1986:169) en Bosch en Victor (1996:108) ook as toename bestempel kon word.

\subsubsection{Die verhouding tussen toename en ander naamtipes gesamentlik beskou}

Globaal beoordeel, het alle persoonstoename die gemeenskaplike kenmerk dat hulle optree as sosiaal verbreide verdringers of herdopings van persone se amptelike name en/of naamderivate. Daar word twee klasse onderskei wat ten opsigte van gebruikstatus en betekenis verskil. Die sentrale klas ("egte" toename) is essensieel betekenisgelaaide (konnoterende) herdopings. Hulle vertoon, soos aangedui is, diversiteit ten opsigte van grammatiese gedrag. Grammaties tree hulle op as vervangers van name plus vanne, name en vanne, en ook as aanvullende bousels. Die nie-sentrale groep is toename slegs in soverre hulle optree as verdringers van amptelike name. Hieronder ressorteer verbleekte respektitels en troetelvorme, asook voorlettername en naam-en-van-akronieme. Betekenisgewys staan hulle nader aan amptelike voomame en voornaamvervormings. Soos voorname is hulle nie-konnoterende identifiseringsinjale. Hulle verskil van egte toename ten opsigte van grammatiese gedrag. Verbleekte respektitels en troetelvorme tree slegs naamvervangend op, terwyl voorlettername en naam-en-van-akronieme in die reël naam-en-van-substituerend ingespan word.

Hierdie toenaamklasse kan saam met ander persoonsnaamtipes gerangskik word op 'n skaal met arbitrêre identifisering en konnoterende identifisering as pole (vgl. meegaande skaal). 


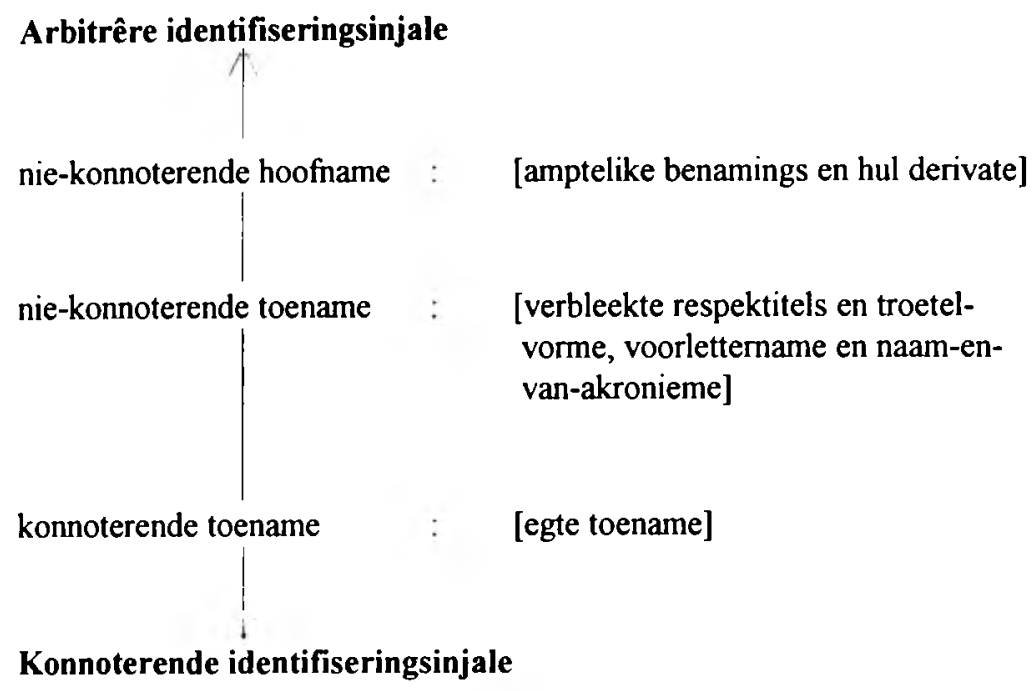

Hierdie skaal ondervang die volgende reëlmaat: hoe nader 'n naamtipe aan die konnoterende pool van die skaal geleë is, hoe groter sy herdopingsbereik. Niekonnoterende toename is slegs herdopings van amptelike name en derivate daarvan. Die herdoping is in hoofsaak ook slegs gerig op voorname en voornaamderivate. Hierdie tendens word onder meer weerspieël in die gebruik van verbleekte respektitels in vaste kombinasie met voomaamderivate en voorlettername:

Verbleekte respektitel plus voornaamderivaat:

Jan Diergaardt $>$ Boet Joe, Saul Willemse $>$ Boet Sok, Cornelia Leukes > Ousie La

Verbleekte respektitel plus voorletternaam:

Alex (Eliek) Brown $>$ Boeta $E$

Hierteenoor is sowel nie-konnoterende amptelike benaminge as nie-konnoterende toenaambenoemings onderhewig aan konnoterende herdoping:

Herdoping van amptelike benaminge:

Frank Hendricks $>$ Sinnie Hendricks, Jonnie Esau > Jonnie

Polttiek

Herdoping van verbleekte toenaambenoemings

Boeta Hendricks > Boeta Mankie, Boetie Hendricks > Boetie

Bollings, Mollie Witbooi $>$ Mollie Naald

Die kombinering van nie-konnoterende verbleekte vorme met vanvervangende egte toename soos in Boetie Bollings, Boeta Mankie, Mollie Naald suggereer dat 
herdoping deur middel van egte toename in sulke gevalle eers plaasvind ná die vaslegging van verbleking. In teenstelling met die voornaamgerigtheid van niekonnoterende herdoping is konnoterende herdoping primêr vangerig. Egte toename in vanvervangingsfunksie konstitueer naamlik $65,2 \%$ van die totale aantal egte toename (vgl. punt 3.4 in die bylaag).

\subsection{Semantiese aard van egte persoonstoename}

\subsubsection{Semantiese kategorieë}

Egte toename in Calvinia omsluit naas enkele semanties ondeursigtige toename soos Bollings en Doel (in Boetie Bollings en Koos Doel) 'n wye verskeidenheid semanties deursigtige ondertipes:

(a) Verwantskapstoename waaronder

- $\quad$ egverbandidentifiseerders: Lena Jan, Mita Onk (die vroue van Jan Nel en Hennie Onk) en

- nasaatidentifiseerders: Jonnie Viskop (die seun van Boy Viskop), Jan Engelsman (vermoedelik die buite-egtelike kind van 'n Engelsman).

(b) Woonplektoename waaronder

- plaasnaamidentifiseerders: Flip Soetwater, Hennie Toekoms (eienaars/ bewoners van die plase Soetwater en Toekoms),

- woonwykidentifiseerders: Willie Pella (wat in die woonwyk Pella gewoon het) en

- woonerfidentifiseerders: Pieterman Fairyland (wat op die woonerf Fairyland gewoon het).

(c) Herkomstoename: Fred Wynberg, Gert Hantam (onderskeidelik afkomstig uit Wynberg en die Hantam-distrik).

(d) Beroepstoename: Koos Inspekteur (hy was 'n skaapinspekteur), Karel Balloon (hy was werksaam by iemand met die van Balloon).

(e) Generasiegapingtoename: Groot mister Louw x Klein mister Louw.

(f) Takseerders van fisieke eienskappe: Jakop Skaapkop, Gert Lip.

(g) Takseerders van geesteseienskappe: Mal Nana, Jan Job

(h) Takseerders van neigings: Kaatjie Kekkelhek, Martiens Raashek.

(i) Takseerders van uiterlike vertoon: Willem Brilletjies, Bêtjie Opdoen/ (iepak, Oupa Wilveer. 
Tipes (a) tot (e) kan getipeer word as verband-identifiserende toename, dit is toename wat meer bepaald die draer karakteriseer in terme van sy sosiale verbande/verankerdheid en in die reël affekties neutraal aangewend word. Tipes (f) tot (i) is weer individu-takserende toename, dit is toename wat óok identifiserend is, maar meer bepaald iets te kenne gee oor die draer as individu, ongeag sy sosiale verbande, en taksering of oordeelvelling as semantiese pluswaarde het.

Hierdie indeling van toename in verbandidentifiseerders en individutakseerders en die uitgangspunt dat alle toename wesenlik identifiserend van aard is, berus op die aanname dat 'n pragmatiese perspektief op toename vra vir 'n verrekening van die impak van funksie en die wisselwerking tussen groep en individu op die betekenis van toename. Teen dié agtergrond doen 'n klassifikasiesisteem soos dié van Combrink (1977:40) minder oortuigend aan. Combrink subkategoriseer persoonstoename in skertsende/spottende toename (Dina Kromnek) en herkomsidentifiserende toename waaronder verwantskapsname (Hannie-Gert), woon- of herkomsname (Jan Colesburg), beroepsname (Suzie Klere) en eienskapsname (oom Koos Definitief). Die suggestie dat skertsende/spottende toename nie identifiserend van aard is nie, word deur die realiteit weerlê. 'n Toenaambenoeming soos Willie Kees, byvoorbeeld, sinjaleer nie slegs spot nie, maar ook identiteit. Dit kan deur Calvinianers aangewend word om Willie $\mathrm{X}$ te onderskei van Willie Chef, Willie Sharp, Willie Lombard, ensovoorts. Voorts is dit te betwyfel of sodanige klassifikasiemodel geskik sou wees om semantiese verskuiwing effektief te verklaar (vgl. 2.2.3).

\subsubsection{Die grammatiese gedrag van semantiese kategorieë}

Die ondersoek weerspieël die volgende tendense insake die semantiese aard en/of gebruik van egte toename in die Calvinia-omgewing:

(a) Naam-en-van-verdringende toename (Johanna $\mathrm{X}>$ Nôintjie Kat) en naamvervangers (X Bailey > Stompie Bailey) is uitsluitlik individutakserend (vgl. punt 3.5.1 en 3.5.2 in die bylaag). By vanvervangers is die frekwensie van individutakseerders (Jannie X > Jannie Skouers) beduidend hoër as dié van verbandidentifiseersers (Jannie Visagie > Jannie Krans: "Jannie, eienaar van die plaas Krans") (vgl. punt 3.5.3 in die bylaag). By aanvullende toename is die frekwensie van semantiese ondertipes feitlik dieselfde (vgl. punt 3.5.4 in die bylaag). By vooropgeplaaste aanvullende toename word verbandidentifiseerders (Klein mister Louw) vryelik afgewissel met individutakseerders (Rooi Willem), terwyl agteropgeplaaste aanvullende toename (Sarel Christians senior) weer slegs verbandidentifiserend funksioneer. 
(b) Die globale frekwensie van vanvervangers is beduidend hoër: vanvervangend $(65,2 \%)>$ aanvullend $(11,9 \%)>$ naamvervangend $(11,6 \%)$ $>$ naam-en-van-vervangend $(11,2 \%)$ (vergelyk punt 3.4 in die bylaag).

(c) Die globale gebruiksfrekwensie van individutakseerders $(67,4 \%)$ is aansienlik hoër as dié van verbandidentifiseerders $(32,6 \%)$ (vgl. punt 2.4 in die bylaag).

(d) Individutakseerders sprei in alle posisies, maar tree veral vanvervangend op: vanvervangend $(57,5 \%)>$ naamvervangend $(17,2 \%)>$ naam-en-vanvervangend $(16,7 \%)>$ aanvullend $(8,6 \%)$ (vgl. punt 3.2 in die bylaag).

(e) Verbandidentifiseerders tree slegs vanvervangend en aanvullend op: vanvervangend $(81,1 \%)>$ aanvullend $(18,9 \%)>$ naam-en-van-vervangend + naamvervangend $(0 \%)$ (vgl. punt 3.1 in die bylaag).

Die gebruiksvoorkeur aan individutakserende toename (c) sou onder meer in verband gebring kon word met die algemene neiging in 'n gemeenskap om eienskappe en handelinge van individue wat nie strook met die aanvaarde norm of reëlmaat nie, te veroordeel of te bestraf (vgl. Coetzee, 1975). Verbandlegging met die bekende lê ' $n$ hele aantal individutakseerders in Calvinia ten grondslag. So byvoorbeeld is veeboerdery en vleisproduksie as tipiese plaaslike aktiwiteit 'n hoogs produktiewe sfeer vir toenaamskepping: Isak Beeslewer, Gert Beeslippe, Johan Bokram, Isak Mof, Willempie Niertjie, Jan Riempies, Jakop Skaapkop. Voorts spruit heelwat toename voort uit 'n assosiasie met onder meer omgewingspesifieke wildediere en veldplante (Petrus Akkedis, Koos Erdman, Suring), bekende mak diere (Duifie Gous, Gert Hondjie) en alledaagse gebruiksitems (Soplepel, Vicks Nel).

Die globale voorkeur aan vanvervangers (b) sou onder meer herlei kon word tot die hoë konsentrasie voornaamgenote (Gert, Hans(ie), Jan(nie)) en selfs naam-envan-genote (Jan Visagie, Koos Hendricks). Om tussen hulle te onderskei blyk dit logies te wees om toename eerder vanvergangend as naamvervangend aan te wend. 'n Konsekwensie hiervan is dat verskillende vanvervangende toename mekaar by verwysing as onderskeidingsinjale opponeer: Jan Byl x Jan Engelsman x Jan Ghyp x Jan Pou; Hans Hoppies x Hans Kleipyp x Hans Slang. Holland (1990:256) se bevinding insake die gebruik van toename as identifiseringsmeganisme is dus eweneens van toepassing op toenaamgebruike in Calvinia en omgewing: "Many studies indicate the utility of nicknaming as an identifying or classificatory mechanism in cultures where ambiguity exists in the formal naming system."

Die voorkeur aan die gebruik van verbandidentifiserende toename in veral vanvervangingsfunksie (e) kan verklaar word met verwysing na die historiese 
oorsprong van vanne. Baie amptelike vanne/agtername wat tans wêreldwyd in gebruik is, was oorspronklik toename wat in die verlede aan persone toegedig is as 'n meganisme om hulle sosiale verbande of verankerdheid te sinjaleer: Jan Hendriks ("Jan die seun van Hendrik"), Jan Potgieter ("Jan wat potte van koper of yster giet") (vgl. Hoge, 1926:37-41; Van Berkel, 1994:52-54). Die aanwending in Calvinia van beroeps- en verwantskapstoename in vanvervangingsfunksie het ook sodanige verbandleggingsfunksie: Hennie van Wyk $>$ Hennie Toekoms ("Hennie, eienaar van die plaas Toekoms"), Anna Christians > Annatjie Sarel ("Annatjie, vrou van Sarel"). So gesien, is die neiging om verbandidentifiserende toename in Calvinia veral vanvervangend aan te wend, 'n natrilling van 'n oeroue naamgewingspraktyk.

\subsubsection{Semantiese verskuiwing}

Die dinamiek van sosio-kulturele en sosio-ekonomiese kragte kan toenaamoordrag/bynaamoorerwing (Du Plessis, 1984:30; Eksteen, 1978:9) in die hand werk. Hierdie oordrag gaan gepaard met semantiese verskuiwing in twee rigtings: van individutakserend na verbandidentifiserend én van een verbandidentifiserende subkategorie na 'n ander. Eersgenoemde rigting word gemanifesteer in gevalle waar 'n toenaam wat as individutakseerder ontstaan, mettertyd die status van verbandidentifiseerder aanneem. So byvoorbeeld is die toenaam Bok wat as geneigdheidstakseerder aan ene Hendrik Mathys toegedig is (op grond daarvan dat hy flinkvoetig beweeg en oral opgeklouter het), mettertyd gepromoveer tot sowel egverband- as nasaatidentifiseerder. Vergelyk (waar $\rightarrow=$ "oorgedra op/gekoppel aan", $O D=$ "oorspronklike draer" en $\mathrm{O}=$ "ontvanger van benaming”): Bok (Hendrik) Mathys [OD] $\rightarrow$ Tôtie $B o k$ [0 = vrou van oD] en Henry Bok [o = seun van oD].

'n Verdere uitvloeisel van hierdie verskuiwing is die verskynsel dat 'n groepsindividutakserende toenaam deur verbreide toenaamoordrag die status van groepsidentiteitsmerker (wandelvan) verkry. Aan ene Boy Maasdorp is byvoorbeeld die takserende toenaam Viskop toegedig. Hierdie toenaam is nie alleen op sy drie seuns oorgedra nie, maar ook op die seuns se vroue en kinders. Die wandelvan Viskop het gevolglik die amptelike van Maasdorp verdring. Die groepsidentiteitstatus van Viskop (en ook ander wandelvanne soos Beenpens en Hoepel vir twee Van Wyk-families) word talig bevestig deur die gebruik van die by verwysing: Die Viskoppe/Hoepels het gaan piekniek hou.

Die tweede verskuiwingsrigting kom onder meer tot uiting in gevalle waar 'n beroepstoenaam deur toenaamoordrag ' $n$ egverbandidentifiseerder word deurdat 'n werkgewer se van die toenaam van sy manlike werkgewer word, en uiteindelik ook die toenaam van die werkgewer se huweliksmaat: Mister. Jollie [OD = 
werkgewer] $\rightarrow$ Jan Jollie (Jan Lombard) [1ste $0=$ werknemer van OD] $\rightarrow$ Els Jollie (Els Lombard) [2de $0=$ vrou van 1ste 0].

\subsection{Beginsels onderliggend aan die identifiseringsfunksie van egte toename}

Die amptelike benaming en toenaambenoeming vir ' $n$ bepaalde persoon funksioneer pragmaties-semanties enersyds identies en andersyds verskillend. Hulle kom daarin ooreen dat hulle afwisselend ingespan kan word as referensiële uitdrukkings, dit wil sê as taalbousels om die betrokke persoon derdepersoonnoemend in gespreksituasies te identifiseer of te individualiseer (De Klerk, 1978:50-58; Ponelis, 1979:576). So byvoorbeeld word die amptelike naam Willem Louw sowel as die toenaambenoeming Rooi Willem deur Calvinianers aangewend om na die referent "Willem Louw" te verwys. Voorts is die amptelike naam en toenaambenoeming van 'n persoon albei unieke referensiële uitdrukkings, en wel in diè sin dat hulle op enige gegewe oomblik slegs op een bepaalde referent/persoon betrekking het (De Klerk, 1978:54). Die verskil tussen die twee naamtipes is egter daarin gesetel dat die toenaambenoeming op grond van sy beskrywende aard meer dikwels 'n noukéúriger identifisering van die betrokke persoonsreferent in die hand werk: "Omdat die gebruik van 'n bynaam in baie gevalle eienskapsverwant is, bied byname 'n semanties ryker en meer eksplisiete denotasie as amptelike name" (Bosch \& Victor, 1996:105).

Calvinianers sou derhalwe by geleentheid voorkeur kon gee aan die semanties deursigtige benaming Rooi Willem om die referent "Willem Louw" suksesvol te identifiseer. Gebruiksvoorkeur aan toenaambenoemings word dus gerig deur 'n beginsel van suksesvolle identifikasie.

Enkele persone staan onder meer as een toenaambenoeming bekend: Johanna Hendricks > Hannie Appie, Hannie Doel; Johannes x > Hans Geld, Hans Prokureur, Grool Hans Pienaar. Die wyse waarop 'n persoon se toenaambenoemings mekaar as onderskeidingsinjale opponeer, word naas die beginsel van suksesvolle identifikasie gerig deur pragmatiese faktore soos situasionele omstandighede en die beginsel van veronderstelde bekendheid. Johannes $\mathbf{x}$, byvoorbeeld, het op 'n stadium saam met 'n jonger naamgenoot in die kerkraad gedien. Die twee is gevolglik deur kerkraadslede van mekaar onderskei deur gebruikmaking van die generasiegapingonderskeiers Groot Hans $\mathrm{x}$ en Klein Hans $X$. Die benaming Hans Geld word tans veelvuldig gebruik omdat Hans $\mathrm{X}$ se sukses as sakeman wyd bekend is. Die minder gebruiklike benaming Hans Prokureur word weer in hoofsaak gebruik in gevalle waar 'n spreker veronderstel dat die gespreksgenoot kennis dra van die feit dat Hans $\mathrm{X}$ op ' $\mathrm{n}$ stadium by ' $\mathrm{n}$ prokureur werksaam was. 


\section{Slotopmerkings}

Die kensketsing van persoontoename in hierdie bydrae sou nouliks as totaal vernuwend bestempel kon word, en het meer bepaald betrekking slegs op tocnaamgebruike in Calvinia en omgewing. Daar word egter vertrou dat veral die aksent op die grammatiese gedrag van toename en die onderverdeling van toename in verbandidentifiseerders en individutakseerders nie alleen sal meehelp om onsekerhede rondom die begrip toenaam op te klaar nie, maar dat dit ook benut sal kan word in die ontsluiting van toenaamgebruike in ander afgebakende kontekste. Soos aangetoon, is die fokus van dié ondersoek meer bepaald funksiespesifiek en sosio-histories, dit wil sê gerig op die identifiseringsfunksie van toename in die ouer Afrikaanssprekende gemeenskap van Calvinia en omgewing. Ek stel in die vooruitsig 'n opvolgondersoek wat toegespits sal wees op toenaamskepping in die hedendaagse Calvinia met die klem op ander funksies soos die solidariteitsfunksie van toename en die gebruik van toename vir die afkondiging van sosiale norme. So 'n ondersoek behoort 'n aanduiding te kan gee van die mate waarin toenaamtendense in die ouer Calvinia steeds in hedendaagse Calvinia van krag is. Wat hierdie bydrae wil beklemtoon, is dat konteksspesifieke studies binne die raamwerk van 'n pragmatiese analise waarskynlik die sleutel is tot die ontsluiting van taalverskynsels (soos toename) in hul volle draagwydte.

\section{Bylaag:}

\section{Persoonstoename in die Calvinia-distrik: statistiese analise}

\section{Totale aantal toenaambenoemings: 372}

\section{Betekenisonderskeidinge}

2.1 Verbleekte respektitels

$040(10,75 \%)$

(Suster Farao, Boet Esau)

2.2 Verbleekte troetelvorme

$047(12,63 \%)$

(Mannetjies Speelman, Koekie Sass)

2.3 Voorlettertoename en naam-en-van-

akronieme

$009(02,42 \%)$

(F (ef), A-Louw)

2.4 Egte toename

$276(74,19 \%)$

2.4.1 Verbandidentifiseerders

$090(32,61 \%)$

(Isak Gouda, Bet Mejôl) 
2.4.2 Individutakseerders

(Mal Dawid, Koos Moordenaar)

$186(67,39 \%)$

3. Grammatiese gedrag van egte toename

3.1 Grammatiese gedrag van verbandidentifiseerders

3.1.1 Naam-en-van-vervangend

$000(00,00 \%)$

3.1.2 Naamvervangend

$000(00,00 \%)$

3.1.3 Vanvervangend

$073(81,11 \%)$

3.1.4 Aanvullend

$017(18,89 \%)$

3.2 Grammatiese gedrag van individutakseerders

3.2.1 Naam-en-van-vervangend

$031(16,67 \%)$

3.2.2 Naamvervangend

$032(17,20 \%)$

3.2.3 Vanvervangend

$107(57,53 \%)$

3.2.4 Aanvullend

$016(08,60 \%)$

3.4 Grammatiese gedrag van egte toename gesamentlik

3.4.1 Naam-en-van-vervangend

$031(11,23 \%)$

3.4.2 Naamvervangend

$032(11,59 \%)$

3.4.3 Vanvervangend

$180(65,22 \%)$

3.4.4 Aanvullend

$033(11,96 \%)$

3.5 Spreiding van semantiese kategorieë by egte toename

3.5.1 Naam-en-van-vervangend

3.5.1.1 Verbandidentifiserend

3.5.1.2 Individutakserend

$000(000,00 \%)$

$031(100,00 \%)$

3.5.2 Naamvervangend

3.5.2.1 Verbandidentifiserend

3.5.2.2 Individutakserend

$000(000,00 \%)$

$032(100,00 \%)$

3.5.3 Vanvervangend

3.5.3.1 Verbandidentifiserend

3.5.3.2 Individutakserend

$073(40,56 \%)$

$107(59,44 \%)$

3.5.4 Aanvullend

3.5.4.1 Verbandidentifiserend

3.5.4.2 Individutakserend

$017(51,52 \%)$

$016(48,48 \%)$ 


\section{Bibliografie}

Alford, Richard D. 1987. Naming and Identity: A Cross-Cultural Study of Personal Naming Practices. New Haven, Connecticut : HRAF Press

Anoniem. 1955. Calvinia Skool-Eeufees 1855-1955. Paarl : Fisher en Seuns.

Bosch, B 1994. Bynaamnavorsing: 'n Bestekopname. Nomina Africana, 8(2):27-39.

Bosch, Barbara \& De Klerk, Vivian. 1994. Oor Klokkies en Sticks: Byname in 'n Afrikaanssprekende gemeenskap. Nomina Africana, 8(2):41-57.

Bosch, Barbara \& Victor, James. 1996. Byname in 'n universiteitskoshuis: indrukwekkende sosiolinguistiese merkers. Tydskrif vir Geesteswetenskappe, 36(2):104-118.

Coetzee, A J. 1975. Byname. Tydskrif vir Volkskunde en Volkstaal, 31(2):16-18.

Combrink, J.G.H. 1977. Afrikaanse Persoonsnaamkunde as studiegebied Taalfaselte, 22(1) 1-55.

Combrink, J.G.H 1982. Noem hom op sy naam - die nut van die vokatief. In: Van Jaarsveld, G.J. (red ) Wat sê jy? - Studies oor Taalhandelinge in Afrikaans. Johannesburg : McGraw-Hill. p. 1-24.

Crewe-Brown, Mike 1992. Calvinia. Fourways : C.B.M. Publishing ('n inligtingsbrosjure).

De Klerk, W.J. 1978. Inleiding tot die Semantiek Durban : Butterworth.

De Klerk, Vivian \& Bosch, Barbara 1996 Naming Practices in the Eastern Cape Province of South Africa. Names, 44(3): 167-188.

Dik, S.C. 1978. Functional Grammar. Amsterdam : North-Holland.

Du Plessis, C. 1984. Die mededinging tussen die manlike en vroulike voornaamwoord in Afrikaans Bloemfontein: UOVS (M.A.-verhandeling)

Eksteen, Louis. 1978. Die Afrikaanse woord. Pretoria/Kaapstad : Academica.

Fillmore, C.J. 1981 Pragmatics and the Description of Discourse. In: Cole, P. (ed.) Radical Pragmatics New York/London: Academic Press p. 143-166.

Halliday, M.A.K. 1973. Explorations in the Functions of Langwage. London : Edward Amold (Publishers)

Hendricks, F.S 1988. Prolepsis in Afrikaans Bellville : UWK. (D.Litt -proefskrif.)

Hoge, J 1926 Ons familiename Die Huisgenoot: 37-41, Des. 24.

Hoge, J. 1945. Herkoms van familiename. Die Huisgenoot : 14-15, Feb. 9.

Holland, T J 1990. The Many Faces of Nicknames. Names, 27:255-272.

Landman, K J.H. 1986. Byname In: Paper, P.E. (ed.) Names/Name 1983. Pretoria : RGN. p. $167-177$.

Lawson, E, Leslie, P. \& Skipper, J. 1990. The Systematic Study of Personal Nicknames: A Small Step Forward. Names, 38(4) 253-254.

Leslie, Paul L. \& Skipper, James K. 1990. Toward a Theory of Nicknames: A Case for Socio-Onomastics Names, 34(4):273-282

Levinson, S C 1983. Pragmatics. Cambridge/London : Cambridge University Press

Links, Tony 1989. So praat ons Namakwalanders. Kaapstad : Tafelberg.

Lyons, J 1977. Semantics Vol. I \& II Cambridge/London : Cambridge University Press.

Ponelis, F. A. 1979. Afrikaanse simaksis Pretoria: Van Schaik

Skipper, J.K. 1989. Public Nicknames of Famous Football Players and Coaches: A SocioHistorical Analysis and Comparison. Sociological Spectrum, 9:103-104.

Smit, AP 1946. Na honderd Jaar: Eenfees N.G. Gemeente Calvinia 1847-1947. Kaapstad : Nasionale Pers.

V L.V. Calvinia 1968. Lig en gewig uit die Hamam. s.l. : s n.

Van Berkel, G. 1994. De man bij zijn naam genoemd. Onze Taal, 63(2/3):52-54

Van Dyk, T J. 1992. Pragmatiek, Jef Verschueren en IPrA. Suid-Afrikaanse Tydskrif vir Taalkunde, 10(1) 20-26 
Van Niekerk, A.A.J. 1976. Daar's meer in 'n bynaam. Tydskrif vir Volkskunde en Volkstaal, 32(2):31-32.

Van Rooyen, G.H. 1961. Voortrekker-byname. Tydskrif vir Volkskunde en Volkstaal, 17(3):6-13.

Van Waart, S. 1975. Byname. Tydskrif vir Volkskunde en Volkstaal, 31(3):35-36

Verschueren, Jef. 1987. Pragmatics as a Theory of Linguistic Adaption: First working document. Antwerp : International Pragmatics Association. 
